\title{
VARIASI METODE DAN MEDIA PEMBELAJARAN DARING UNTUK MENGAKOMODASI MODALITAS BELAJAR
}

\author{
Mouren Wuarlela \\ Politeknik Negeri Ambon \\ e-mail: mourenwuarlela@,gmail.com
}

\begin{abstract}
Abstrak: Pembelajaran pada dasarnya dibangun dari interaksi antarkomponen pembelajaran seperti pengajar, pemelajar, materi ajar, metode pembelajaran, media pembelajaran, dll. Suatu pembelajaran dikatakan berhasil jika pembelajaran tersebut efektif dan efisien, serta mencapai tujuan yang ditargetkan. Banyak faktor yang dapat mempengaruhi tercapainya pembelajaran yang efektif dan efisien. Faktor yang mendasar adalah rancangan pembelajaran. Dalam proses perancangan pembelajaran, pengajar diharapkan memiliki kemampuan dan keterampilan misalnya ketika menentukan metode dan media pembelajaran. Akan tetapi ada komponen mendasar yang mesti diperhatikan pengajar dalam merancang pembelajaran yakni modalitas belajar pemelajar. Jika pengajar memahami dengan baik modalitas belajar pemelajar, maka pemahaman tersebut akan mempermudah pengajar dalam merancang pembelajaran dalam hal ini menentukan metode dan media pembelajaran yang tepat dan bervariasi sehingga pembelajaran diharapkan tidak hanya berkualitas tetapi juga menarik dan tidak membosankan, serta dapat meningkatkan motivasi dan minat belajar pemelajar. Selain modalitas belajar, pengajar pun harus peka terhadap situasi dan kondisi pelaksanaan pembelajaran. Pada era industri 4.0 ini, pengajar diperhadapakan dengan tantangan yang sebenarnya bukan lagi menjadi tantangan yang baru yakni pembelajaran dalam jaringan (daring). Pembelajaran daring menjadi objek menarik yang dibahas di berbagai web seminar (webinar) maupun diskusi-diskusi. Realitas yang terjadi, banyak pengajar mengalami shock dan kebingungan karena harus memperbiasakan diri dengan pembelajaran daring akibat wabah Covid-19 yang mengharuskan belajar dari rumah. Dengan adanya tantangan tersebut, pengajar mesti lebih matang dalam merancang pembelajaran. Melalui tulisan ini, penulis ingin memberi gambaran rancangan pembelajaran daring dengan memanfaatkan pemahaman pengajar terhadap modalitas belajar dalam menentukan metode dan media pembelajaran yang tepat, menarik, dan bervariasi.
\end{abstract}

Kata Kunci: metode pembelajaran, media pembelajan, pembelajaran daring, modalitas belajar 


\title{
THE VARIATION OF METHOD AND MEDIA IN ONLINE LEARNING TOWARD LEARNING MODALITY
}

\author{
Mouren Wuarlela \\ Ambon State Polytechnic \\ e-mail: mourenwuarlela@gmail.com
}

\begin{abstract}
Learning is basically built from interactions of learning components such as edicators, learners, teaching materials, learning methods, learning media, etc. The learning to be successful if the learning to be effective and efficient, as well as achieving purpose of learning. Many factors can affect the achievement of effective and efficient learning. But, the fundamental factor is design of learning. In the learning design process, educator are expected to have the ability and skills when determining methods and media of learning. However, there is a fundamental component that must be considered by educator in designing learning is learning modality of learners. If the educator knows the learning modalities of the learner, they can determining varied methods and media of learning, so that learning is expected to be not only quality but also interesting and enjoying. They can increase motivation and learner interest in learning. In addition, educator must also be understanding the situation and conditions of learning. In this industrial 4.0 era, educator are confronted with a reality that are no longer a new, namely online learning. Online learning becomes an interesting object in webinars and discussions. Many educator are shock and confused because they have to familiarize themselves with online learning due to the Covid19 outbreak which requires learning from home. Educator must be focus more on designing learning. In this paper, the author wants to give an overview of online learning designs and how to determining method and media of learning toward learning modality.
\end{abstract}

KeyWords: learning method, learning media, online learning, learning modality 


\section{A. PENDAHULUAN}

Pembelajaran daring (dalam jaringan) pada era industri 4.0 berperan penting dalam pelaksanaan pembelajaran yang tidak dapat dilakukan dengan tatap muka secara langsung. Pada pelaksanaannya, pembelajaran daring sudah diterapkan seiring berkembangnya teknologi, informasi, dan komunikasi, tetapi tidak secara intensif, karena paham tentang pembelajaran tatap muka secara langsung (konvensional) masih menjadi pilihan utama dalam pelaksanaan pembelajaran sehingga belum semua pengajar menggunakan media daring untuk pelaksanaan pembelajaran. Pembelajaran daring hanya dilakukan dalam situasi yang mendesak seperti ketika pengajar berada di luar daerah yang tidak memungkinkan untuk bertatap muka secara langsung. Akan tetapi, belakangan ini, dunia pendidikan diperhadapkan dengan wabah Covid-19 yang dapat dijadikan alasan untuk mengubah pola pikir pengajar terhadap media pembelajaran. Artinya pada masa ini, pembelajaran daring menjadi keharusan dan pilihan utama dalam pelaksanaan pembelajaran. Tidak dapat dihindari bahwa banyak pengajar mengalami shock dan kebingungan dalam merancang pembelajaran yang secara utuh dilaksanakan secara daring. Hal tersebut berdampak pada proses pembelajaran, kualitas pembelajaran, dan hasil pembelajaran.

Banyak faktor yang mesti diperhatikan dalam mendukung pembelajaran baik secara langsung maupun daring. Akan tetapi, perancangan pembelajaranlah yang menjadi komponen utama dalam pembelajaran karena pembelajaran yang berhasil hanya dapat dicapai melalui perencanaan yang baik dan tepat (Hakim, 2009). Dalam merancang pembelajaran, pengajar tidak hanya mempersiapkan materi, tujuan, dan waktu pembelajaran tetapi menentukan metode dan media pembelajaran yang tepat dan menarik. Dalam proses merancang pembelajaran, pengajar pun harus memahami dengan baik modalitas atau gaya belajar pemelajar. Modalitas atau gaya belajar pemelajar dimaknai sebagai gaya belajar yang khas yang dimiliki setiap individu yang terdiri atas modalitas belajar visual, audio, dan kinestetik (Suyono \& Haryanto, 2014: 148). Karena modalitas belajar pemelajar beragam, maka diperlukan metode dan media pembelajaran yang bervariasi. Sebaik apa pun materi dirancang, jika pengajar tidak mampu menerapkan metode dan media pembelajaran yang menarik dan bervariasi untuk mengakomodasi dan memfasilitasi kebutuhan modalitas atau gaya belajar pemelajar, maka pembelajaran tersebut tidak dapat mencapai tujuan pembelajaran yang ditargetkan. Dengan demikian, meskipun pembelajaran dilakukan secara daring, proses pembelajaran harus tetap bervariasi dan tidak monoton. Rancangan pembelajaran yang paling mudah dan bervariasi dapat dirancang berdasarkan modalitas belajar pemelajar.

Berdasarkan wawancara dengan beberapa pemelajar, juga analisis keluhan pemelajar via media sosial (medsos), ditemukan fakta bahwa pada umumnya dalam pembelajaran daring, materi disajikan dengan media modul atau teks bacaan (PPT, MS Word, PDF) dan berbasis teori. Hal tersebut justru membuat pemelajar memerlukan banyak waktu untuk belajar karena untuk membaca modul saja sudah menghabiskan banyak waktu, belum lagi menyelesaikan tugas dan latihan yang diberikan. Kalaupun ada pertanyaan dari pemelajar, maka pertanyaan itu akan dibahas dengan metode diskusi dan dilakukan setiap kali pertemuan sepanjang semester. Hal ini mengurangi motivasi belajar pemelajar karena untuk membaca saja pemelajar sudah kewalahan dan 
akhirnya mereka lebih memilih mengerjakan tugas dan tidak berdiskusi karena yang menjadi prioritas mereka adalah hasil akhir dan bukan proses.

Selain itu, masih banyak pembelajaran daring berbentuk penugasan baik mandiri maupun kelompok sehingga muncul keluhan "Kuliah online bukan tugas online" pada kalangan pemelajar. Pembelajaran yang dibangun bersifat monoton. Dengan demikian, modalitas belajar yang akan paling ditonjolkan adalah modalitas belajar visual. Hal ini mungkin tampak sederhana tetapi memiliki dampak yang besar bagi perkembangan belajar pemelajar.

Pembelajaran yang mengedepankan salah satu modalitas belajar akan bersifat tidak merata dan tidak seimbang karena kemampuan dan keterampilan pemelajar dalam pembelajaran berbeda. Akan terjadi ketimpangan dalam memperoleh dan memahami materi yang disajikan. Dengan demikian judul yang diangkat penulis adalah "Variasi Metode dan Media Pembelajaran untuk Mengakomodasi Kebutuhan Belajar Modalitas Belajar".

Penulisan ini dibuat dengan tujuan untuk membuka wawasan pengajar dan memberi gambaran rancangan pembelajaran daring dengan memanfaatkan pemahaman pengajar terhadap modalitas belajar dalam menentukan metode dan media pembelajaran yang tepat, menarik, dan bervariasi.

\section{B. METODEPENELITIAN}

Tulisan ini merupakan tulisan konseptual yang ditawarkan penulis untuk memberi gambaran rancangan pembelajaran dengan menggunakan perpaduan metode dan media pembelajaran yang bervariasi untuk mengakomodasi kebutuhan modalitas belajar dalam pembelajaran daring. Penulisan ini akan dibahas dengan menggunakan teori modalitas belajar VAK (Visual, Audiotory, Kinesthetic) yang dikembangkan oleh Rita Dunn dan Kenneth Dunn. Melalui tulisan ini, penulis memaparkan langkahlangkah untuk merancang pembelajaran dengan memadukan metode dan media pembelajaran secara eksplanatif dan memberi gambaran rancangan pembelajaran untuk membuka wawasan pengajar serta mempermudah pengajar dalam merancang pembelajaran secara prediktif.

\section{PEMBAHASAN}

\section{Metode Pembelajaran}

Metode pembelajaran merupakan langkah penting dalam pembelajaran yang disesuaikan dengan materi, tujuan, dan kegiatan pembelajaran (Sumiati \& Asra, 2009:12). Oleh sebab itu seorang pengajar diharapkan memiliki kemampuan dan keterampilan dalam menentukan metode pembelajaran yang efektif dan efisien. Menurut Sumiati \& Astra (2009: 92-96), penggunaan metode pembelajaran dapat ditentukan dengan tepat (efektif) dengan memperhatikan hal-hal berikut.

1. Kesesuaian metode pembelajaran dengan tujuan pembelajaran.

2. Kesesuaian metode pembelajaran dengan materi pembelajaran.

3. Kesesuaian metode pembelajaran dengan kemampuan guru.

4. Kesesuaian metode pembelajaran dengan kondisi siswa. 
5. Kesesuaian metode pembelajaran dengan sumber dan fasilitas tersedia.

6. Kesesuaian metode pembelajaran dengan situasi kondisi belajar mengajar.

7. Kesesuaian metode pembelajaran dengan waktu yang tersedia.

8. Kesesuaian metode pembelajaran dengan tempat belajar.

Selain materi dan tujuan pembelajaran, pengajar pun mesti tanggap menyesuaikan metode pembelajaran dengan kondisi pemelajar salah satunya modalitas belajar sehingga dapat memotivasi pemelajar serta mencapai pembelajaran yang efektif dan efisien khususnya dalam pembelajaran daring. Metode pembelajaran yang dapat digunakan antara lain metode; ceramah, tanya jawab, diskusi, kontekstual, simulasi, demonstrasi dan eksperimen, inquiry dan discovery, kisah/cerita, permainan (games), penugasan, modul, latihan dan praktik, dll.

\section{Media Pembelajaran}

Kata media berasal dari bahasa Latin dan merupakan bentuk jamak dari kata medium yang secara harafiah berarti perantara sumber pesan dengan penerima pesan. Media juga dapat dipahami sebagai manusia, materi, kejadian, yang membuat pemelajar mampu memperoleh pengetahuan, keterampilan, dan sikap (Gerlach \& Ely dalam Arsyad, 2011:3). Kata pembelajaran dimaknai sebagai interaksi belajar mengajar antara pengajar dan pemelajar. Dengan demikian media pembelajaran dapat dartikan sebagai alat atau perantara yang digunakan dalam interaksi belajar mengajar untuk mencapai tujuan pembelajaran yang maksimal. Pada umumnya media yang digunakan dalam kegiatan pembelajaran adalah media komunikasi (Susilana \& Riyana, 2009:12). Dengan demikian media dapat dijadikan sebagai alat saluran komunikasi dalam pembelajaran. Oleh sebab itu, media pembelajaran mestinya dapat menyampaikan pesan pengirim pesan (pengajar) yang disampaikan oleh media tersebut sehingga dapat diterima dan dipahami oleh penerima pesan (pemelajar) juga menjawab tantangan pembelajaran daring sebagai pengganti pembelajaran tatap muka secara langsung di kelas.

Media pembelajaran dapat dikelompokkan menjadi lima kelompok besar yakni media visual diam, media visual gerak, media audio, media audio visual diam, dan media audio visual gerak (Susilana \& Riyana, 2009:14). Kelompok media ini diharapkan dapat memenuhi kebutuhan modalitas belajar sehingga tercapai pembelajaran daring yang maksimal dan berkualitas.

\section{Modalitas Belajar}

Modalitas belajar menurut teori VAK (Visual, Audiotory, Kinesthetic) yang dikembangkan oleh Rita Dunn dan Kenneth Dunn, terdiri atas 3 tipe yakni tipe belajar visual, audio, dan kinestetik (Samani, 2014, 149). Modalitas belajar visual dapat dirtikan sebagai tipe yang lebih mengutamakan indera pelihat. Pemelajar dengan tipe belajar visual akan lebih cepat memahami materi yang disajikan dengan cara melihat seperti membaca teks. Modalitas belajar audio lebih cenderung memanfaatkan indera pendengar. Materi akan cepat dipahami dengan cara mendengarkan, seperti belajar dengan mendengarkan radio. Selanjutnya, pemelajar dengan modalitas belajar kinestetik lebih suka belajar melalui gerakan-gerakan fisik. Ketiga tipe ini akan dibahas dan menjadi dasar untuk mendesain media yang bervariasi sebagai perantara 
komunikasi dalam pembelajaran daring.

Pada kenyataannya, ada pemelajar yang hanya memiliki salah satu modalitas belajar, namun ada juga pemelajar yang memiliki tipe belajar gabungan baik dua atau tiga tipe. Biasanya tipe gabungan yang dimiliki adalah pemelajar dengan tipe belajar audio visual, visual kinestetik, dan audio kinestetik. Pemelajar dengan tipe belajar audio visual dapat menggunakan indera pendengar saja, atau indera pelihat saja, tetapi lebih sering menggunakan indera pendengar dan pelihat sekaligus, misalnya melalui media video.

Begitupula dengan pemelajar dengan tipe audio kinestetik yang selain dapat menggunakan indera pendengar atau gerakan fisik, lebih cenderung memanfaatkan indera pelihat dan gerakan fisik secara bersamaan, misalnya melalui media teks narasi deskriptif seperti membaca buku-buku cerita yang berorientasi pada alur cerita yang mendeskripsikan aksi atau gerakan tubuh. Tipe gabungan lainnya adalah tipe audio kinestetik yang tidak hanya suka mendengar tapi juga bergerak-gerak saat belajar. Namun, pemelajar dengan tipe audio kinestetik lebih menyukai pembelajaran yang sifatnya praktik dan latihan.

\section{Penentuan Metode dan Media Pembelajaran sesuai Modalitas Belajar}

Menentukan metode dan media pembelajaran bukanlah hal yang mudah apalagi memadukan metode dan media pembelajaran yang tepat, menarik, dan bervariasi, namun tidak juga sulit jika pengajar memahami modalitas belajar pemelajar. Selain harus memiliki kemampuan dan keterampilan yang baik, seorang pengajar setidaknya harus memahami modalitas belajar pemelajar bukan hanya dalam menentukan metode dan media, tetapi juga memadukan metode dan media pembelajaran yang tepat sasaran dan tepat guna. Ketika seorang pengajar memiliki kemauan, keyakinan, dan usaha, semua harapan terlaksananya pembelajaran yang efektif, efisien, dan berkualitas dapat terpenuhi. Berikut langkah-langkah menentukan metode dan media, serta perpaduan metode dan media pembelajaran yang disesuaikan dengan modalitas belajar pemelajar.

\section{Langkah-Langkah Merancang Pembelajaran}

1. Tentukan materi yang akan disajikan dan dibahas.

2. Tentukan tujuan pembelajaran yang akan dicapai.

3. Tentukan waktu yang diperlukan dalam pelaksanaan pembelajaran.

4. Tentukan metode pembelajaran yang sesuai dengan materi dan tujuan pembelajaran.

5. Tentukan media yang cocok untuk mendukung metode pembelajaran sesuai materi yang telah ditentukan.

6. Rancangkan pembelajaran dengan memadukan metode dan media yang telah dipilih sesuai modalitas belajar. Upayakan metode dan media yang dipilih dan digunakan dapat mencakup keseluruhan modalitas belajar (sesuai dengan pemahaman pengajar terhadap pemelajar). Selain itu, sebisa mungkin gunakan metode dan media yang berbeda atau bervariasi untuk setiap materi.

7. Lakukan refleksi di akhir pembelajaran untuk mengetahui motivasi dan respon pemelajar terhadap proses pembelajaran yang dilaksanakan. 


\section{Contoh Rancangan Pembelajaran}

Rancangan pembelajaran yang dirancang untuk Mata Kuliah Bahasa Indonesia Pertemuan I - Pertemuan III.

\section{Pertemuan I}

\section{Materi}

Tujuan Pembelajaran

Waktu
:1.Sejarah dan Kedudukan Bahasa Indonesia

\section{Fungsi Bahasa Indonesia}

:Menunjukkan pengetahuan yang memadai tentang sejarah, kedudukan, dan fungsi bahasa Indonesia

: 2X50 menit

Kegiatan Pendahuluan (dapat diterapkan di seluruh pertemuan):

1. Pembelajaran tatap muka dapat dilakukan dengan menggunakan aplikasi zoom, google meeting, atau aplikasi lain yang mendukung.

2. Untuk forum penugasan, latihan, dan praktik dapat menggunakan aplikasi google classroom atau WAG (Whatsapp Grup).

3. Kelas dibuka dengan sapaan (waktu yang diperlukan maksimal 5 menit).

4. Kehadiran dilakukan dengan mengisi form kehadiran atau presensi dapat langsung didata diawal pertemuan (waktu yang diperlukan maksimal 10 menit).

\section{Rancangan Kegiatan Pembelajaran Materi Sejarah dan Kedudukan Bahasa Indonesia:}

\begin{tabular}{|c|c|c|c|}
\hline Metode Pembelajaran & Media Pembelajaran & Waktu & Tipe Belajar \\
\hline $\begin{array}{l}\text { 1. } \\
\text { Metode ceramah: } \\
\text { Pengajar menjelaskan kegiatan- } \\
\text { kegiatan yang akan dilakukan selama } \\
\text { proses pembelajaran. }\end{array}$ & $\begin{array}{l}\text { 1. Media visual diam: } \\
\text { Didukung dengan teks } \\
\text { pada slide power point. }\end{array}$ & 10 menit & $\begin{array}{c}\text { Audio, Visual, Audio } \\
\text { Visual }\end{array}$ \\
\hline $\begin{array}{l}\text { 2. Metode kisah/cerita: } \\
\text { Pengajar menyajikan kisah/ cerita } \\
\text { sejarah perkembangan bahasa } \\
\text { Indonesia. }\end{array}$ & $\begin{array}{l}\text { 2. Media audio visual } \\
\text { gerak: } \\
\text { Materi disajikan dengan } \\
\text { media video (cerita } \\
\text { bergambar) atau film } \\
\text { dokumenter pendek } \\
\text { tentang sejarah } \\
\text { perkembangan bahasa } \\
\text { Indonesia ( di dalamnya } \\
\text { memuat tentang } \\
\text { kedudukan bahasa } \\
\text { Indonesia) berdurasi } \\
\text { maksimal } 3 \text { menit. }\end{array}$ & 5 menit & $\begin{array}{c}\text { Audio, Visual, } \\
\text { Kinestetik, Audio } \\
\text { Visual, Audio Visual } \\
\text { Kinestetik }\end{array}$ \\
\hline $\begin{array}{l}\text { 3. Metode praktik: } \\
\text { Pemelajar diberi kesempatan untuk } \\
\text { membuat rangkuman/ kesimpulan/ } \\
\text { sinopsis/ resensidengan } \\
\text { menggunakan gaya bahasa sendiri } \\
\text { dengan memperhatikan penggunaan } \\
\text { bahasa Indonesia yang baik dan } \\
\text { benar secara lisan. }\end{array}$ & $\begin{array}{l}\text { 3. Media visual audio } \\
\text { gerak: } \\
\text { Tugas dibuat dengan } \\
\text { media video. Video } \\
\text { dikirim ke google } \\
\text { classroom. }\end{array}$ & 20 menit & $\begin{array}{c}\text { Audio, Visual, } \\
\text { Kinestetik, Audio } \\
\text { Visual, Audio Visual } \\
\text { Kinestetik }\end{array}$ \\
\hline
\end{tabular}




\section{Rancangan Kegiatan Pembelajaran Materi Fungsi Bahasa Indonesia:}

\begin{tabular}{|c|c|c|c|}
\hline Metode Pembelajaran & Desain Pembelajaran & Waktu & Tipe Belajar \\
\hline $\begin{array}{l}\text { 1. Metode Ceramah: } \\
\text { Pengajar menyajikan pokok-pokok } \\
\text { fungsi bahasa Indonesia dis ertai } \\
\text { penjelasan singkat. }\end{array}$ & $\begin{array}{l}\text { 1. Media audio visual: } \\
\text { Didukung dengan teks } \\
\text { pada slide power } \\
\text { point disertai suara. }\end{array}$ & 10 menit & $\begin{array}{c}\text { Audio, Visual, Audio } \\
\text { Visual }\end{array}$ \\
\hline $\begin{array}{l}\text { 2. Metode Games: } \\
\text { Pengajar menampilkan potongan- } \\
\text { potongan subpokok fungsibahasa } \\
\text { Indonesia secara acak (format jpg } \\
\text { agar lebih mudah dipindahkan). }\end{array}$ & $\begin{array}{l}\text { 2. Media Visual: } \\
\text { Disajikan dalam bentuk } \\
\text { slide power point. }\end{array}$ & 20 menit & Visual \\
\hline $\begin{array}{l}\text { 3. Metode Games } \\
\text { Pemelajar menyusun fungsi-fungsi } \\
\text { tersebut sesuaidengan pokok-pokok } \\
\text { fungsi bahasa Indonesia yang sudah } \\
\text { disajikan sebelumnya. }\end{array}$ & $\begin{array}{l}\text { 3. Media visual gerak: } \\
\text { Susunan fungsi-fungsi } \\
\text { bahasa Indonesia dikirim } \\
\text { melalui google } \\
\text { classroom/WAG. }\end{array}$ & 10 menit & $\begin{array}{l}\text { Visual, Kinestetik, } \\
\text { Visual Kinestetik }\end{array}$ \\
\hline
\end{tabular}

Kegiatan Penutup (dapat diterapkan di seluruh pertemuan):

1. Pengajar melakukan evaluasi. Evaluasi dilakukan berdasarkan kemampuan mengintegrasikan pengetahuan, keterampilan, nilai, sikap, dan pemikiran kreatif untuk membangun konteks baru. (waktu yang diperlukan maksimal 10 menit)

2. Pengajar melakukan refleksi terkait pembelajaran (waktu yang diperlukan maksimal 10 menit)

3. Pengajar mengakhiri kelas. (waktu yang diperlukan maksimal 5 menit)

\section{Pertemuan II}

Materi

Tujuan Pembelajaran

Waktu
:Penulisan Ejaan Bahasa Indonesia

1. Pemakaian Huruf

2. Penulisan Kata

3. Penulisan Singkatan dan Akronim

4. Pemakaian Tanda Baca

:Menerapkan penggunaan ejaan bahasa Indonesia yang tepat dalam penulisan

:2X50 menit

Rancangan kegiatan pembelajaran untuk materi penulisan ejaan bahasa Indonesia:

\begin{tabular}{|c|c|c|c|}
\hline Metode Pembelajaran & Media Pembelajaran & Waktu & Tipe Belajar \\
\hline $\begin{array}{l}\text { 1. } \\
\text { Petode ceramah: } \\
\text { Pengajar menjelaskan kegiatan- } \\
\text { kegiatan yang akan dilakukan selama } \\
\text { proses pembelajaran dan } \\
\text { mengirimkan teks Pedoman Umum } \\
\text { Ejaan Bahasa Indonesia. }\end{array}$ & $\begin{array}{l}\text { 1. } \\
\text { Media visual diam: } \\
\text { Didukung dengan teks } \\
\text { pada slide power point. }\end{array}$ & 10 menit & $\begin{array}{c}\text { Audio, Visual, Audio } \\
\text { Visual }\end{array}$ \\
\hline $\begin{array}{l}\text { 2. Metode Inqury dan discovery } \\
\text { Pemelajar menganalis is kesalahan } \\
\text { penulisan ejaan pada berita online } \\
\text { dengan berpedoman pada PUEBI. } \\
\text { Berita dan hasil analisis berita }\end{array}$ & $\begin{array}{l}\text { 2. Media visual gerak: } \\
\text { Pengajar menggunakan } \\
\text { media teks berita yang } \\
\text { dicari sendiri oleh } \\
\text { pemelajar secara daring. }\end{array}$ & 20 menit & $\begin{array}{c}\text { Audio, Visual, } \\
\text { Kinestetik, Audio } \\
\text { Visual, Audio Visual } \\
\text { Kinestetik }\end{array}$ \\
\hline
\end{tabular}


dikirim melalui google

classroom.(pemelajar meyertakan

link berita)

3. Metode presentasi \& diskusi: Pemelajar mempresentasikan hasil kerja (melalui aplikasi zoom) dan didiskusikan dalam forum komentar (perwakilan pemelajar yang memiliki hasil kerja terbaik).

4. Metode latihan dan praktik: Pemelajar mendengar berita dan menulis kembali berita tersebut dengan memperhatikan penulisan ejaan bahasa Indonesia yang tepat(teks berita yang disusun dikirim ke google classroom dan dijadikan nilai tugas).
3. Media visual audio gerak:

Presentasi s ecara langsung oleh pemelajar.

4. Media audio: Pemelajar mendengar berita berdurasi maksimal 2 menit melalui rekaman berita tanpa gambar untuk mempertajam keterampilan menyimak.

\section{Kegiatan Penutup:}

1. Pengajar melakukan refleksi terkait pembelajaran (waktu diperlukan maksimal 10 menit)

2. Pengajar mengakhiri kelas. (waktu yang diperlukan maksimal 5 menit)

\section{Pertemuan III}

\section{Materi}

: 1. Membangun konteks teks akademik

2. Menelusuri dan menganalisis model teks akademik :

- Mengidentifikasi ciri-ciri teks akademik

- Menganalisis pentingnya teks akademik

Tujuan Pembelajaran : Mengeksplorasi Teks Akademik dalam Genre Mikro

Waktu

: 2X50 menit

Rancangan Kegiatan Pembelajaran untuk Materi Penulisan Ejaan Bahasa Indonesia:

\begin{tabular}{|c|c|c|c|}
\hline Metode Pembelajaran & Media Pembelajaran & Waktu & Tipe Belajar \\
\hline $\begin{array}{l}\text { 1. Metode ceramah: } \\
\text { Pengajar menjelaskan kegiatan- } \\
\text { kegiatan yang akan dilakukan selama } \\
\text { proses pembelajaran dan } \\
\text { menjelaskan secara singkat konsep } \\
\text { teks akademik dan teks } \\
\text { nonakademik. }\end{array}$ & $\begin{array}{l}\text { 1. Media visual diam: } \\
\text { Didukung dengan teks } \\
\text { pada slide power point. }\end{array}$ & 10 menit & $\begin{array}{c}\text { Audio, Visual, } \\
\text { Kinestetik, Audio } \\
\text { Visual, Audio Visual } \\
\text { Kinestetik }\end{array}$ \\
\hline $\begin{array}{l}\text { 2. Metode pemodelan dan tebak- } \\
\text { tebakan: } \\
\text { - Pengajar menunjukkan } 2 \text { contoh } \\
\text { teks tanpa memberi tahu teks } \\
\text { manakah yang digolongkan dalam } \\
\text { teks akademik dan teks } \\
\text { nonakademik dengan memberi } \\
\text { kode "teks 1" untuk teks akademik } \\
\text { dan "teks 2" untuk teks } \\
\text { nonakademik. } \\
\text { - Pengajar memberi tebak-tebakan } \\
\text { yang berisi pertanyaan tentang } \\
\text { "siapa aku". Pengajar menyebutkan } \\
\text { salah satu ciri teks dan pemelajar }\end{array}$ & $\begin{array}{l}\text { 2. Media audio visual } \\
\text { gerak: } \\
\text { Pengajar } \\
\text { menggunakan } \\
\text { animasi dengan suara } \\
\text { yang menunjukkan } \\
\text { ciri-ciri teks. }\end{array}$ & 40 menit & $\begin{array}{c}\text { Audio, Visual, } \\
\text { Kinestetik, Audio } \\
\text { Visual, Audio Visual } \\
\text { Kinestetik }\end{array}$ \\
\hline
\end{tabular}


menyebutkan dengan cepat pada kolom chat (aplikasi yang digunakan adalah zoom). Jika syarat yang disampaikan pengajar ada pada teks pertama maka pemelajar menjawab "teks 1"

- Pengajar memilih beberapa pemelajar secara acak untuk menjelaskan alasan memilih teks.

3. Metode inqury dan discovery: Setelah permainan selesai, pemelajar sudah mendapat contoh teks akademik dan teks nonakademik beserta cirri-cirinya. Selanjutnya pemelajar mencari contoh-contoh teks lainnya yang serupa.

4. Metode presentasidan diskusi: Pemelajar mempresentasikan hasil kerja (melalui aplikasi zoom) dan didiskusikan dalam forum komentar (perwakilan pemelajar yang memiliki hasil kerja terbaik).
3. Media visual gerak: Pemelajar menggunakan media teks untuk analisis.

4. Media visual audio gerak: Pres entasis ecara langsung oleh pemelajar.
Visual, Kinestetik, Visual Kinestetik

Audio, Visual, Kinestetik, Audio Visual, Audio Visual Kinestetik

\section{Kegiatan Penutup:}

1. Pengajar melakukan refleksi terkait pembelajaran. (waktu yang diperlukan maksimal 10 menit)

2. Pengajar mengakhiri kelas. (waktu yang diperlukan maksimal 5 menit)

\section{KESIMPULAN}

Pembelajaran yang efektif dan efisien dapat tercapai melaui perancangan pembelajaran yang baik dan matang. Dalam merancang pembelajaran, pengajar tidak hanya membutuhkan kemampuan dan keterampilan dalam menentukan metode dan media pembelajaran tetapi dapat menyesuaikan komponen-komponen tersebut dengan modalitas belajar. Modalitas belajar pemelajar sangat beragam. Oleh sebab itu, pemahaman pengajar terhadap modalitas belajar yang beragam dapat mempermudah pengajar dalam menentukan metode dan media pembelajaran yang tepat serta bervariasi. Dengan demikian penentuan metode dan media pembelajaran yang disesuaikan dengan modalitas belajar tidak hanya diharapkan dapat menghasilkan pembelajaran yang efektif dan efisien, tetapi juga menarik, menyenangkan, dan tidak monoton sehingga dapat memotivasi dan meningkatkan minat belajar pemelajar meski harus belajar dari rumah. 


\section{DAFTAR PUSTAKA}

Arsyad Azhar. 2011. Media Pembelajaran. Jakarta: PT Raja Grafindo Persada.

Hakim Lukmanul. 2009. Perencanaan Pembelajaran. Bandung: CV Wacana Prima.

Sumiati, Asra. 2009. MetodePembelajaran. Bandung: CV Wacana Prima.

Susilana Rudi, Riyana Cepi. 2009. Media Pembelajaran: Hakikat, Pengembangan,

Pemanfaatan, dan Penilaian. Bandung: CV Wacana Prima.

Suyono \& Haryanto. 2014. Belajar dan Pembelajaran: Teori dan Konsep Dasar.

Bandung: PT Remaja Rosdakarya 
Variasi Metode dan Media Pembelajaran Daring untuk Mengakomodasi Modalitas Belajar 